\title{
Harvesting of Chlorella sorokiniana BR001 cultivated in a low-nitrogen medium using different techniques
}

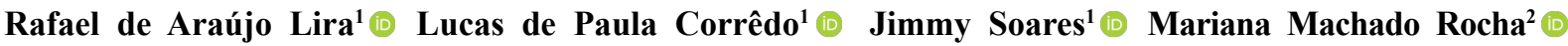 Antonio Teixeira de Matos $^{1}$ (D) Jane Selia dos Reis Coimbra ${ }^{3}$ (D) Marcio Arêdes Martins ${ }^{1^{*}}$ (D)}

${ }^{1}$ Departamento de Engenharia Agrícola, Universidade Federal de Viçosa (UFV), 36570-900, Viçosa, MG, Brasil. E-mail: aredes@ufv.br. ${ }^{*}$ Corresponding author.

${ }^{2}$ Departamento de Biologia Vegetal, Universidade Federal de Viçosa (UFV), Viçosa, MG, Brasil. ${ }^{3}$ Departamento de Tecnologia de Alimentos, Universidade Federal de Viçosa (UFV), Viçosa, MG, Brasil.

ABSTRACT: The harvesting process is a current challenge for the commercial production of microalgae because the biomass is diluted in the culture medium. Several methods have been proposed to harvest microalgae cells, but there is not a consensus about the optimum method for such application. Herein, the methods based on sedimentation, flocculation, and centrifugation were evaluated on the recovery of Chlorella sorokiniana BR001 cultivated in a low-nitrogen medium. C. sorokiniana BR001 was cultivated using a low-nitrogen medium to trigger the accumulation of neutral lipids and neutral carbohydrates. The biomass of C. sorokiniana BR001 cultivated in a low-nitrogen medium showed a total lipid content of 1.9 times higher $(23.8 \pm 4.5 \%)$ when compared to the biomass produced in a high-nitrogen medium (12.3 $\pm 1.2 \%)$. In addition, the biomass of the BR001 strain cultivated in a low-nitrogen medium showed a high content of neutral carbohydrates (52.1 $\pm 1.5 \%$ ). The natural sedimentation-based process was evaluated using a sedimentation column, and it was concluded that C. sorokiniana BR001 is a non-flocculent strain. Therefore, it was evaluated the effect of different concentrations of ferric sulfate $\left(0.005\right.$ to $\left.1 \mathrm{~g} \mathrm{~L} \mathrm{~L}^{-1}\right)$ or aluminum sulfate $\left(0.025\right.$ to $\left.0.83 \mathrm{~g} \mathrm{~L}^{-1}\right)$ on the flocculation process of C. sorokiniana BR001, but high doses of flocculant agents were required for an efficient harvest of biomass. It was evaluated the centrifugation at low speed (300 to 3,000 g) as well, and it was possible to conclude that this process was the most adequate to harvest the non-flocculent strain C. sorokiniana BR001.

Key words: microalgae, ferric sulfate, aluminum sulfate, sedimentation, centrifugation.

Colheita de Chlorella sorokiniana BR001 cultivada em um meio com baixo teor de nitrogênio utilizando diferentes técnicas

RESUMO: O processo de colheita é um desafio atual para a produção comercial de microalgas porque a biomassa é diluida no meio de cultivo. Diversos métodos têm sido propostos para coletar células de microalgas, porém não existe um consenso sobre um método ótimo para tal aplicação. Neste estudo, métodos baseados em sedimentação, floculação e centrifugação foram avaliados na recuperação de Chlorella sorokiniana BR001 cultivada em um meio com baixo teor de nitrogênio. C. sorokiniana BR001 foi cultivada em um meio com baixo teor de nitrogênio para induzir ao acúmulo de lipídeos e carboidratos neutros. A biomassa de C. sorokiniana BR001 cultivada em um meio com baixo teor de nitrogênio apresentou um teor de lipídeos 1,9 vezes superior (23,8 $\pm 4,5 \%)$, quando comparada à biomassa produzida em um meio com alto teor de nitrogênio (12,3 $\pm 1,2 \%$ ). Adicionalmente, a biomassa da linhagem BR001 cultivada em um meio com baixo teor de nitrogênio apresentou alto teor de carboidratos neutros (52,1 $\pm 1,5 \%$ ). O processo baseado em sedimentação natural foi avaliado utilizando uma coluna de sedimentação e concluiu-se que C. sorokiniana BR001 é uma linhagem não floculante. Portanto, o efeito de diferentes concentrações de sulfato férrico $\left(0,005\right.$ a $\left.1 \mathrm{~g} \mathrm{~L}^{-1}\right)$ ou sulfato de alumínio $\left(0,025\right.$ a $\left.0,83 \mathrm{~g} \mathrm{~L} \mathrm{~L}^{-1}\right)$ foram avaliados no processo de floculação de C. sorokiniana BR001, mas altas doses de floculantes foram necessárias para uma colheita de biomassa eficiente. Também foi avaliada a centrifugação em baixa velocidade (300 a $3.000 \mathrm{~g}$ ), e foi possível concluir que este processo constituiu o mais adequado para a colheita da linhagem não floculante C. sorokiniana BR001.

Palavras-chave: microalgas, sulfato de ferro, sulfato de alumínio, sedimentação, centrifugação.

\section{INTRODUCTION}

Harvesting of microalgal biomass is considered a bottleneck in algae farms because the biomass is generally diluted in the medium ( 0.5 to $4 \mathrm{~kg}$ of dry weight per $\mathrm{m}^{-3}$ ), and many microalgae with biotechnological potential are planktonic (i.e. free-floating) organisms that show density values similar to water (TIRON et al., 2017). Microalgal cultures are considered stable systems because the surface of microalgal cells presents negative charges that repel other cells, and microalgae are

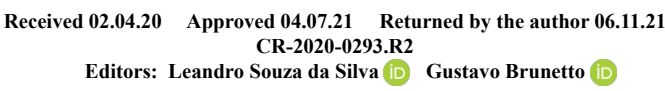


generally found in a dispersed state (SINGH \& PATIDAR, 2018).

Harvesting of microalgae biomass requires costly and complex processes that can reach up to $30 \%$ of the total costs of production (FASAEI et al., 2018). Different methods to harvest microalgal cells have been proposed for a large number of species (TAPARIA et al., 2016). Sedimentation shows low operational costs when compared to other methods of biomass harvest (FASAEI et al., 2018), but the slowness of this process may be a problem for microalgae with a fast metabolism. Catabolism reactions may occur during the harvest process leading to undesired changes in the biochemical composition of the microalgae before their extraction.

To overcome the slow settling of nonflocculent microalgae strains, the use of flocculants have been proposed as a promising and cheap alternative to improve the harvest processes (WAN et al., 2015). Chemical flocculation is widely used in industries for water treatment (VANDAMME; FOUBERT; MUYLAERT, 2013), and different chemical flocculant agents have been successfully used in the harvest of several microalgal strains (WAN et al., 2015). Flocculation is also used as a secondary harvesting method to shorten the duration of the primary harvesting process (e.g. centrifugation) and increase the maximum cell recovery rate (KNUCKEY et al., 2006).

Centrifuges are a robust alternative to process large volumes of microalgae culture in a short time (SPOLAORE et al., 2006). Many types of centrifuges are commercially available (e.g. disc stacked centrifuge and scroll centrifuge), and the equipment can be readily incorporated in microalgal downstream processes. Centrifuges diminish or abolish the use of chemical flocculant agents which are not desired in some specific applications, like the use of microalgae as food and feed.

Despite the several harvest methods proposed in the literature, it is unlikely to determine an optimum harvesting method for all microalgae strains. Indeed, it is expected that the method and conditions of biomass harvesting should be specific for each microalgal strain. Chlorella is currently the second most commercially-produced microalga, and it has been considered a promising feedstock for advanced biofuels production (FALCONÍ et al., 2021; LIU \& CHEN, 2014; ROCHA et al., 2017). Specifically, the strain C. sorokiniana BR001 shows a fast growth synthetic media in comparison to other Chlorophyta strains isolated from Brazilian freshwater reservoirs (ROCHA et al., 2017), and it is considered a promising strain for the treatment of wastewaters from sugarcane ethanol biorefinery which are largely produced in Brazil (FALCONÍ et al., 2020).

Although Chlorella has been used at a commercial scale and novel algae farming application have been proposed, the harvesting process requires investigation because the self-flocculation is a trait observed only in some strains of the genus Chlorella (ALAM et al., 2014; ESCAPA et al., 2015; RAS et al., 2011). Previous studies showed the efficiency of different methods on the harvest of Chlorella cultivated in rich-nitrogen media (AHMAD et al., 2014; NGUYEN et al., 2014). However, little is known about the harvesting of Chlorella cells cultivated in a low-nitrogen medium (ILLMAN; SCRAGG; SHALES, 2000). The main objective of this study was to determine the best method of biomass harvesting for a specific Chlorella strain cultivated in a low-nitrogen medium. The methods of sedimentation, centrifugation, and flocculation were evaluated on the harvesting of $C$. sorokiniana BR001 cultivated in a low-nitrogen medium. Algae farming using low-nitrogen media is largely adopted as a strategy to trigger the accumulation of neutral lipids and neutral carbohydrates (LIU \& CHEN, 2014).

The strain $C$. sorokiniana BR001 was first cultivated in rich- and low-nitrogen media for evaluation of the accumulation of C-rich biochemical classes (i.e. total lipids and total neutral carbohydrates). Then, the different methods of biomass harvesting were evaluated on the harvesting of $C$. sorokiniana BR001 cultivated in a low-nitrogen medium. It was evaluated the natural sedimentation to evaluate if of C. sorokiniana BR001 presents the self-flocculation phenotype. A careful evaluation of flocculant agents was performed because their optimum dosage may vary one order of magnitude for different microalgae (DEMIR et al., 2020). Different centrifugation speeds and times were evaluated because centrifuges will be common equipment in algae farms and biorefineries as they are required in biorefining processes (AMORIM et al., 2020).

\section{MATERIALS AND METHODS}

\section{Strain and growth conditions}

C. sorokiniana BR001 was obtained from the Collection of Microalgae of the Department of Plant Biology, Universidade Federal de Viçosa (Minas Gerais, Brazil). The BR001 strain was maintained in a rich-nitrogen medium for Chlorella ellipsoidea (WATANABE, 1960). 
Cultivation of C. sorokiniana BR001 in rich-and lownitrogen media

The BR001 strain was cultivated in $2 \mathrm{~L}$ photobioreactors containing 1.6 L of the low-nitrogen medium proposed by ILLMAN et al. (2000) or the rich-nitrogen medium for Chlorella ellipsoidea (WATANABE, 1960). Photobioreactors were maintained in photoautotrophic growth conditions at $25 \pm 2{ }^{\circ} \mathrm{C}, 16 / 8 \mathrm{~h}$ photoperiod (light/dark cycle), and irradiance at bench height of $83 \mu$ mols photons $\mathrm{m}^{-2}$ $\mathrm{s}^{-1}$ obtained using 40-watt daylight fluorescent lamps. A diaphragm pump was used to provide mixing for cultivations in flasks. Cultures of $C$. sorokiniana BR001 were collected on day 14, and the biomass was harvested by centrifugation $(20,000 \mathrm{~g}$ for 20 $\min$ ), freeze-dried and stored at $-20{ }^{\circ} \mathrm{C}$. Freeze-dried biomass was used for the determination of total neutral carbohydrates based on the phenol-sulfuric acid method (CRAIGIE \& HELLEBUST, 1978), and the determination of total lipids was performed according to the Bligh and Dyer method (BLIGH \& DYER, 1959; ZHU, 2002).

Cultivation of C. sorokiniana BR001 for evaluation of the harvesting methods

The BR001 strain was cultivated in 20 L photobioreactors containing 16 L of lownitrogen medium proposed by ILLMAN et al. (2000). Photobioreactors were maintained in the aforementioned photoautotrophic growth conditions. Samples of C. sorokiniana BR001 culture were collected on day 17 for evaluation of the following methods of biomass recovery: sedimentation, flocculation, and centrifugation. An independent microalgae cultivation was carried out for each biomass harvesting method evaluated in this study. The harvesting methods were evaluated in quadruplicate.

\section{Biomass harvest by sedimentation}

Natural sedimentation of $C$. sorokiniana BR001 was evaluated using an acrylic sedimentation column with a diameter of $0.1 \mathrm{~m}$ and a height of $1 \mathrm{~m}$. The sedimentation column was filled with a culture of $C$. sorokiniana BR001, and the cell suspension was homogenized using a rod for $1 \mathrm{~min}$ to ensure its uniform distribution along the column. Then, $10 \mathrm{~mL}$ of samples were collected from top to bottom of the column using the column scale as reference $(0,20$, $40,60$ and $80 \mathrm{~cm})$ in different times $(0,30,180,240$, 300 and $360 \mathrm{~min}$ ).

Optical density at $670 \mathrm{~nm}$ of the samples was determined using a UV-Vis spectrophotometer. Biomass dry weight was determined according to a standard curve correlating the optical density against different dry weights of the $C$. sorokiniana BR001. Recovery efficiency was calculated according to equation 1.

Recovery efficiency $(\%)=\frac{\text { mass of microalga recovered } \times 100}{\text { mass of microalga initial culture }}(1)$

\section{Biomass harvest by flocculation}

Flocculation of $C$. sorokiniana BR001 biomass was performed using ferric sulfate or aluminum sulfate. The culture of $C$. sorokiniana BR001 was poured into a $500 \mathrm{~mL}$ beaker and the flocculant was added. The beaker was placed in the jar test apparatus and maintained for 10 seconds at $160 \mathrm{rpm}$ and $25^{\circ} \mathrm{C}$, then the rotation was reduced to $20 \mathrm{rpm}$ and kept for more $5 \mathrm{~min}$. The jar test apparatus is the equipment used for the uniform stirring of multiple samples for the evaluation of different types and doses of flocculant. The maximum speed achieved by the jar test apparatus was $160 \mathrm{rpm}$ (velocity gradient of about $340 \mathrm{~s}^{-1}$ ). Rotation of the jar test apparatus was turned off and samples were taken at different times $(15,30$ and 60 $\mathrm{min}$ ) during the flocculation process for determination of the recovery efficiency (Equation 1).

The following concentrations of ferric sulfate were used $\left(\mathrm{g} \mathrm{L}^{-1}\right): 0 ; 0.005 ; 0.01 ; 0.025 ; 0.05$; $0.1 ; 0.17 ; 0.25 ; 0.33 ; 0.5$ and 1 . The concentrations of aluminum sulfate used where $\left(\mathrm{g} \mathrm{L}^{-1}\right): 0 ; 0.025 ; 0.05$; $0.083 ; 0.17 ; 0.25 ; 0.33 ; 0.42 ; 0.5 ; 0.67$ and 0.83 . Those optimum concentrations of flocculants were previously determined in preliminary tests. $\mathrm{pH}$ of the flocculent solutions was adjusted to 6 using $0.1 \mathrm{M} \mathrm{L}^{-1} \mathrm{NaOH}$ prior the test.

\section{Biomass harvest by centrifugation}

Centrifugation of the culture of $C$. sorokiniana BR001 was performed at room temperature using five different speeds $(300 ; 600$; $1,400 ; 2,200$ and $3,000 \mathrm{~g})$ and times $(15,30,60,120$ and $180 \mathrm{~min})$. After the centrifugation samples of the upper phase were taken for estimation of the recovery efficiency (Equation 1).

\section{Statistical analysis}

The experiment was performed in a completely randomized factorial delineation. The results of the cultivation of $C$. sorokiniana BR001 in rich- and low-nitrogen media were submitted to analysis of variance, and means were compared by Duncan's test at a 5\% significance level. Results of biomass harvest by sedimentation were evaluated by response surface methodology, and the results of biomass harvest by flocculation and centrifugation were submitted to 
non-linear regression analysis. The results of this study are presented as mean \pm standard deviation.

\section{RESULTS AND DISCUSSION}

The strain C. sorokiniana BR001 cultivated in a low-nitrogen medium showed a content of total lipids 1.9 times higher $(23.8 \pm 4.5 \%$ in dry weight basis, DW) when compared to the cultivation with a rich-nitrogen medium $(12.3 \pm 1.2 \% \mathrm{DW})$. Cultivation using a lownitrogen medium also allowed a significantly higher (P-value $<0.05$ ) content of total neutral carbohydrates of $(52.1 \pm 1.5 \% \mathrm{DW})$ in comparison to the biomass produced using a rich-nitrogen medium $(48.3 \pm 3.3 \%$ DW). The high content of C-rich molecules suggests that the BR001 is a promising strain for advanced biofuels production (e.g. biodiesel and bioethanol). Thus, the evaluation of harvesting methods was evaluated using a culture of $C$. sorokiniana BR001 produced using a low-nitrogen medium.

Sedimentation is a low-cost process to harvest microalgae biomass. However, microalgae cell densities are generally similar to water density (MILLEDGE \& HEAVEN, 2013). The microalgal cells separate from the medium during the sedimentation process due to gravitation forces, but the similar density of microalgae and medium results in a slow separation (MILLEDGE \& HEAVEN, 2013). Media also show a density similar to the water since few grams of nutrients are added to them; for example, the lownitrogen medium contains $99.4 \%\left(\mathrm{w} \mathrm{w}^{-1}\right)$ of water in its composition (ILLMAN; SCRAGG; SHALES, 2000). Therefore, the efficiency of the sedimentation process was evaluated in C. sorokiniana BR001 cultivated under nitrogen starvation condition because self-flocculation is a trait observed only in some strains of the genus Chorella (ALAM et al., 2014; ESCAPA et al., 2015; RAS et al., 2011). The sedimentation was evaluated using a response surface methodology, and the results showed that the recovery efficiency increased along the top to middle regions of the sedimentation column (Figure 1A). The highest recovery efficiencies were observed on the top of the column (i.e. $0 \mathrm{~cm}$ ) and after $300 \mathrm{~min}$ of sedimentation (Figure 1A). However, the sedimentation process was slow and inefficient to harvest the $C$. sorokiniana BR001 biomass, and it was possible to recover only $30 \%$ of the biomass after 350 min (Figure 1A). These results clearly show that C. sorokiniana BR001 is not a self-flocculent strain.

A study showed that $C$. vulgaris JSC-7 is a self-flocculent strain and cell wall-associated polysaccharides containing a phosphodiester functional group might play an important role in the flocculent phenotype (ALAM et al., 2014). Selfflocculation of a $C$. sorokiniana strain was observed when this microalga was cultivated in swine manure wastewater and medium BG11 at the very high $\mathrm{pH}$ of 12 (ZHANG \& CHEN, 2015). However, the selfflocculation of $C$. sorokiniana was not observed at pH 7 (ESCAPA et al., 2015; XU; PURTON; BAGANZ, 2013; ZHANG \& CHEN, 2015). Those results suggest that some $C$. vulgaris strains but not $C$. sorokiniana are able to self-flocculate at different values of $\mathrm{pH}$. Moreover, flocculation using $\mathrm{pH} 12$ requires high consumption of alkali, especially if the microalgal biomass shows buffering capacity, which might limit the adoption of this strategy in commercial algae farms.

The development of a fast process to harvest microalgae biomass produced in open cultivation systems is necessary to avoid contamination by fast-growing heterotrophic microorganisms that are unavoidably present in cultures produced in open cultivation systems, and changes in the biomass composition like the catabolism of carbohydrates and lipids. For that reason, flocculating agents can be used to promote the aggregation of microalgae cells and increase sedimentation rates (MILLEDGE \& HEAVEN, 2013). A detailed evaluation of flocculating agents is required because the type and dosage of the flocculation agent, medium composition, and microalgae species play an important role in the flocculation process (GRIMA et al., 2003).

Herein, the flocculating agents aluminum sulfate and iron sulfate were evaluated on the sedimentation process of the non-flocculent $C$. sorokiniana BR001 using non-linear regression models that showed high coefficients of determination $\left(\mathrm{R}^{2} \geq 0.92\right)$ (Figures $1 \mathrm{~B}$ and $1 \mathrm{C}$ ). Aluminum sulfate and iron sulfate were considered some of the best flocculating agents to harvest Chlorella cells (PAPAZI et al., 2010), and they resulted in higher efficiency recoveries of $C$. sorokiniana BR001 in comparison to the sedimentation process (Figures $1 \mathrm{~A}$ to $1 \mathrm{C}$ ). It was possible to recover more than $80 \%$ of the biomass using $0.5 \mathrm{~g} \mathrm{~L}^{-1}$ of aluminum sulfate and iron sulfate (Figures $1 \mathrm{~B}$ and $1 \mathrm{C}$ ). Aluminum sulfate and iron sulfate also reduced the duration of the process of biomass harvest, and it was possible to achieve high biomass recovery efficiencies after $15 \mathrm{~min}$ (Figures $1 \mathrm{~B}$ and $1 \mathrm{C}$ ).

According to the non-linear regression models, the flocculant dosage was the most important parameter to achieve high recovery efficiencies (Figures 1B and 1C). Both flocculating agents showed little differences in the recovery rates of BR001 biomass (Figures 1B and 1C). Interestingly, the different harvesting times evaluated in this study 


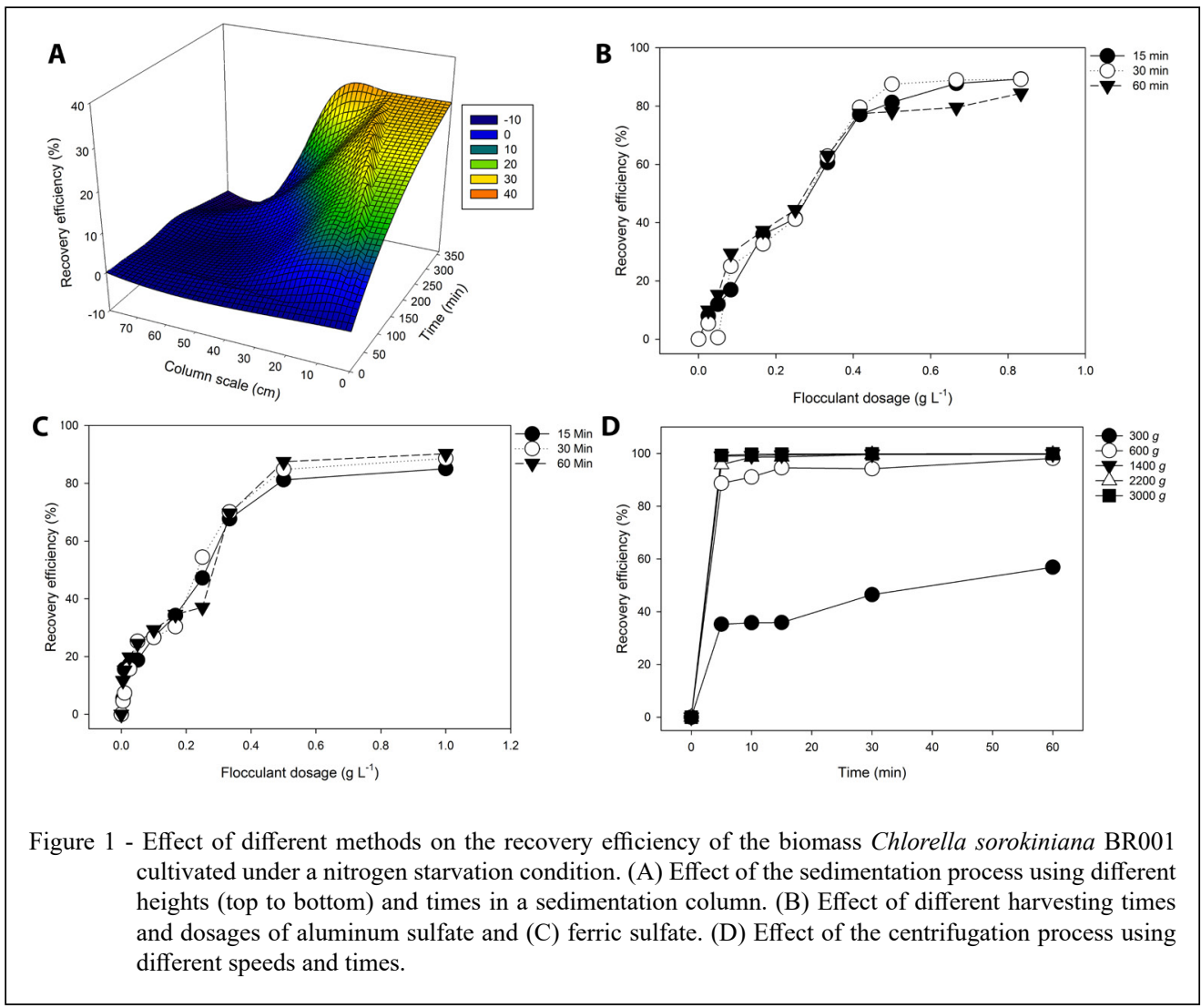

also showed little effect on the maximum recovery of biomass (Figures 1B and 1C). However, the flocculating dosage of $0.5 \mathrm{~g} \mathrm{~L}^{-1}$ resulted in a satisfactory biomass recovery and higher dosages showed little effect on the biomass recovery (Figures $1 \mathrm{~B}$ and $1 \mathrm{C}$ ). For instance, iron sulfate dosages of $0.5 \mathrm{~g} \mathrm{~L}^{-1}$ and 1 $\mathrm{g} \mathrm{L}^{-1}$ resulted in recovery efficiencies of $81.2 \%$ and $85.1 \%$ after $15 \mathrm{~min}$, respectively (Figure $1 \mathrm{C}$ ). These results are in agreement with a previous study that showed that increasing the dosage of aluminum chloride induced the flocculation of $C$. sorokiniana (ZHANG \& CHEN, 2015), and the optimum doses observed herein are in agreement with a previous study that evaluated the harvest of $C$. minutissima (PAPAZI; MAKRIDIS; DIVANACH, 2010).

ZHANG \& CHEN (2015) showed that the optimum dosage of the flocculant varies according to the composition of the medium and $\mathrm{pH}$. Low levels of aluminum chloride (e.g. $\left.10 \mathrm{mg} \mathrm{L}^{-1}\right)$ resulted in efficient flocculation of $C$. sorokiniana cultivated in medium BG11 (ZHANG \& CHEN, 2015). In this current study, the use of $10 \mathrm{mg} \mathrm{L}^{-1}$ iron sulfate and $25 \mathrm{mg} \mathrm{L}^{-1}$ aluminum sulfate did not result in efficient flocculation of $C$. sorokiniana BR001 cultivated in a low-nitrogen medium (Figures 1C and 1D). Indeed, the lownitrogen medium (ILLMAN; SCRAGG; SHALES, 2000) contains 3.7 times more nutrients (i.e. $6.3 \mathrm{~g} \mathrm{~L}^{-1}$ ) than the medium BG11 (i.e. $1.7 \mathrm{~g} \mathrm{~L}^{-1}$ ) (ANDERSEN, 2005). These different compositions of media are possibly related to the different efficiency recoveries observed in these studies.

Centrifugation is considered an efficient process to harvest microalgae biomass (BOROWITZKA \& MOHEIMANI, 2013). Moreover, centrifugation can also be used in combination with other processes like flocculation, sedimentation, and filtration to develop a cheap and efficient process (BOROWITZKA \& MOHEIMANI, 2013). However, previous studies did not evaluate the use of centrifuges to harvest the biomass of C. sorokiniana (XU; PURTON; BAGANZ, 2013; ZHANG \& CHEN, 2015). High costs associated with the use of centrifuges can be reduced with a proper adjustment of the centrifugation process and the use of more efficient and low-cost centrifuge models (BOROWITZKA \& MOHEIMANI, 2013). Thus, the effect of different centrifugation speeds and times harvest of $C$. sorokiniana BR001 cultivated in a low-nitrogen medium was evaluated in detail 
using non-linear regression models that showed high coefficients of determination $\left(\mathrm{R}^{2}>0.99\right)$ (Figure 1D).

High recovery efficiencies were observed using centrifugation in comparison to the sedimentation and flocculation processes (Figure 1). It was possible to achieve high recovery efficiencies in this study using low centrifugal forces $($ e.g. $600 \mathrm{~g})$ that are easily achieved by most of the industrial centrifuges. These results suggest that a robust and expensive centrifuge is not necessary to harvest the cells of $C$. sorokiniana BR001 cultivated in the low-nitrogen medium. High centrifuge speeds clearly improved the recovery efficiency using the different centrifugation times evaluated herein (Figure 1D). On the other hand, the centrifuge speed of $300 \mathrm{~g}$ was inefficient to harvest the biomass of C. sorokiniana BR001, and these recovery efficiencies were similar to those observed in the sedimentation process that resulted in a recovery efficiency lower than $40 \%$ (Figures $1 \mathrm{~A}$ and 1D). However, centrifugation was much faster than the sedimentation process which increases the productivity of algae farms. Increasing the centrifuge speed to $600 \mathrm{~g}$ resulted in a significant increase in the biomass recovery, even using the shortest time of centrifugation evaluated in this study (Figure 1D). A remarkable advantage of centrifuges is the abolishing or reduction of the demand for flocculating agents that are potential contaminants for the biomass and water sources.

\section{CONCLUSION}

The free sedimentation-based process does not result in an efficient harvest of the biomass of the non-flocculent strain Chlorella sorokiniana BR001 cultivated in a low-nitrogen medium. Conversely, the inclusion of ferric sulfate or aluminum sulfate in the sedimentation-based process allows recovery efficiencies higher than $80 \%$ in less than one hour, but a high concentration of these flocculent agents is necessary to achieve adequate recovery efficiencies. Centrifugation presents high recovery efficiency, and the centrifugation speed at $600 \mathrm{~g}$ can harvest more than $90 \%$ of the $C$. sorokiniana BR001 biomass in $5 \mathrm{~min}$. Therefore, centrifuge-based methods are the best alternative to harvest the biomass of the non-flocculent strain Chlorella sorokiniana BR001 cultivated in a low-nitrogen medium.

\section{ACKNOWLEDGEMENTS}

We are thankful to the Conselho Nacional de Desenvolvimento Científico e Tecnológico (CNPq, grant
307147/2015-0). JS was supported by a fellowship from CNPq Brazil (process: 155994/2018-2).

\section{DECLARATION OF CONFLICT OF INTEREST}

The authors declare no conflicts of interest. The founding sponsors had no role in the design of the study; in the collection, analyses or interpretation of data; in the writing of the manuscript; or in the decision to publish the results.

\section{AUTHORS' CONTRIBUTIONS}

All authors contributed equally for the conception and writing of the manuscript. All authors critically revised the manuscript and approved of the final version.

\section{REFERENCES}

AHMAD, A. L. et al. Comparison of harvesting methods for microalgae Chlorella sp. and its potential use as a biodiesel feedstock. Environmental Technology, Sep. 2014. v.35, n.17, p.2244-2253. Available from: <http://dx.doi.org/10.10 80/09593330.2014.900117>. Accessed: Feb. 02, 2020. doi: $10.1080 / 09593330.2014 .900117$

ALAM, M. A. et al. Characterization of the flocculating agent from the spontaneously flocculating microalga Chlorella vulgaris JSC-7. Journal of Bioscience and Bioengineering, Jul. 2014. v.118, n.1, p.29-33. Available from: <http://dx.doi.org/10.1016/j.jbiosc.2013.12.021>. Accessed: Jan. 17, 2020. doi: 10.1016/j.jbiosc.2013.12.021.

AMORIM, M. L. et al. Extraction of proteins from the microalga Scenedesmus obliquus BR003 followed by lipid extraction of the wet deproteinized biomass using hexane and ethyl acetate. Bioresource Technology, Jul. 2020. v.307. Available from: <http:// dx.doi.org/10.1016/j.biortech.2020.123190>. Accessed: Aug. 02, 2020. doi: 10.1016/j.biortech.2020.123190.

ANDERSEN, R. A. Algal culturing techniques. $1^{\text {st }}$. ed. Amsterdam: Elsevier, 2005.

BLIGH, E. G. et al. A rapid method of total lipid extraction and purification. Canadian Journal of Biochemistry and Physiology, Aug. 1959. v.37, n.8, p.911-917. Available from: $<$ http://dx.doi.org/10.1139/ o59-099>. Accessed: Feb. 03, 2020. doi: 10.1139/059-099.

BOROWITZKA, M. A. et al. Algae for biofuels and energy. Dordrecht: Springer Netherlands, 2013. v.5. Available from: $<$ http://dx.doi.org/10.1007/978-94-007-5479-9>. Accessed: Jan. 21, 2020. doi: 10.1007/978-94-007-5479-9.

CRAIGIE, J. S. et al. Handbook of phycological methods: physiological and biochemical methods - volume 2. $1^{\text {st }}$. ed. Cambridge: Cambridge University Press, 1978.

ESCAPA, C. et al. Nutrients and pharmaceuticals removal from wastewater by culture and harvesting of Chlorella sorokiniana. Bioresource Technology, Jun. 2015. v.185, p.276-284. Available from: $\quad<$ http://dx.doi.org/10.1016/j.biortech.2015.03.004>. Accessed: Feb. 03, 2020. doi: 10.1016/j.biortech.2015.03.004.

FALCONÍ, J.H.H. et al. Strain screening and ozone pretreatment for algae farming in wastewaters from sugarcane ethanol biorefinery. 
Journal of Cleaner Production, Feb. 2021, v.282. Available from: $<$ http://dx.doi.org/10.1016/j.jclepro.2020.124522>. Accessed: Mar. 01, 2021. doi: 10.1016/j.jclepro.2020.124522.

FASAEI, F. et al. Techno-economic evaluation of microalgae harvesting and dewatering systems. Algal Research, Apr. 2018 v.31, p.347-362. Available from: <http://dx.doi.org/10.1016/j. algal.2017.11.038>. Accessed: Feb. 04, 2020. doi: 10.1016/j. algal.2017.11.038

GRIMA, E. M. et al. Recovery of microalgal biomass and metabolites: process options and economics. Biotechnology Advances, Jan. 2003. v.20, n.7-8, p.491-515. Available from: $<$ http://dx.doi.org/10.1016/S0734-9750(02)00050-2>. Accessed: Feb. 03, 2020. doi: 10.1016/S0734-9750(02)00050-2.

ILLMAN, A. M. et al. Increase in Chlorella strains calorific values when grown in low nitrogen medium. Enzyme and Microbial Technology, Nov. 2000. v.27, n.8, p.631-635. Available from: $<$ http://dx.doi.org/10.1016/S0141-0229(00)00266-0>. Accessed: Jan. 25, 2020. doi: 10.1016/S0141-0229(00)00266-0.

KNUCKEY, R. M. et al. Production of microalgal concentrates by flocculation and their assessment as aquaculture feeds. Aquacultural Engineering, Oct. 2006. v.35, n.3, p.300-313. Available from: $<$ http://dx.doi.org/10.1016/j.aquaeng.2006.04.001>. Accessed: Jan. 24, 2020. doi: 10.1016/j.aquaeng.2006.04.001.

LIU, J. et al. Biology and industrial applications of Chlorella: advances and prospects. Advances in biochemical engineering/ biotechnology, Dec. 2014, v.123, p.1-35. Available from: <http:// dx.doi.org/10.1007/10_2014_286>. Accessed: Feb. 05, 2020. doi: 10.1007/10_2014_286.

MILLEDGE, J. J. et al. A review of the harvesting of micro-algae for biofuel production. Reviews in Environmental Science and Bio/Technology, Jun. 2013. v.12, n.2, p.165-178. Available from: $<$ http://dx.doi.org/10.1007/s11157-012-9301-z >. Accessed: Jan. 20, 2020. doi: 10.1007/s11157-012-9301-z.

NGUYEN, T. D. P. et al. Harvesting Chlorella vulgaris by natural increase in $\mathrm{pH}$ : effect of medium composition. Environmental Technology, Jun. 2014. v.35, n.11, p.1378-1388. Available from: $<$ http://dx.doi.org/10.1080/09593330.2013.868531>. Accessed: Jan. 19, 2020. doi: 10.1080/09593330.2013.868531.

PAPAZI, A. et al. Harvesting Chlorella minutissima using cell coagulants. Journal of Applied Phycology, Jun. 2010. v.22, n.3, p.349-355. Available from: <http://dx.doi.org/10.1007/s10811009-9465-2>. Accessed: Feb. 14, 2020. doi: 10.1007/s10811-0099465-2.

RAS, M. et al. Experimental study on a coupled process of production and anaerobic digestion of Chlorella vulgaris. Bioresource Technology, Jan. 2011. v.102, n.1, p.200-206. Available from: $<$ http://dx.doi.org/10.1016/j.biortech.2010.06.146>. Accessed: Feb. 09, 2020. doi: 10.1016/j.biortech.2010.06.146.

ROCHA, R. P. et al. Exploring the metabolic and physiological diversity of native microalgal strains (Chlorophyta) isolated from tropical freshwater reservoirs. Algal Research, Dec. 2017. v.28, p.139-150. Available from: <http://dx.doi.org/10.1016/j. algal.2017.10.021>. Accessed: Jan. 24, 2020. doi: 10.1016/j. algal.2017.10.021.

SINGH, G. et al. Microalgae harvesting techniques: a review. Journal of Environmental Management, Jul. 2018. v.217, p.499-508. Available from: <http://dx.doi.org/10.1016/j. jenvman.2018.04.010>. Accessed: Jan. 18, 2020. doi: 10.1016/j. jenvman.2018.04.010

SPOLAORE, P. et al. Commercial applications of microalgae. Journal of Bioscience and Bioengineering, Feb. 2006. v.101, n.2, p.87-96. Available from: <http://dx.doi.org/10.1263/jbb.101.87>. Accessed: Feb. 05, 2020. doi: 10.1263/jbb.101.87.

TAPARIA, T. et al. Developments and challenges in biodiesel production from microalgae: a review. Biotechnology and Applied Biochemistry, Oct. 2016. v.63, n.5, p.715-726. Available from: <http://dx.doi.org/10.1002/bab.1412>. Accessed: Feb. 15, 2020. doi: $10.1002 /$ bab. 1412 .

TIRON, O. et al. Overcoming microalgae harvesting barrier by activated algae granules. Scientific Reports, Dec. 2017. v.7, n.1, p.4646. Available from: <http://dx.doi.org/10.1038/s41598-01705027-3>. Accessed: Jan. 19, 2020. doi: 10.1038/s41598-01705027-3.

VANDAMME, D. et al. Flocculation as a low-cost method for harvesting microalgae for bulk biomass production. Trends in Biotechnology, Apr. 2013. v.31, n.4, p.233-239. Available from: $<$ http://dx.doi.org/10.1016/j.tibtech.2012.12.005>. Accessed: Feb. 21, 2020. doi: 10.1016/j.tibtech.2012.12.005.

WAN, C. et al. Current progress and future prospect of microalgal biomass harvest using various flocculation technologies. Bioresource Technology, May 2015. v.184, p.251-257. Available from: $\quad<$ http://dx.doi.org/10.1016/j.biortech.2014.11.081>. Accessed: Feb. 03, 2020. doi: 10.1016/j.biortech.2014.11.081.

WATANABE, A. List of algal strains in collection at the Institute of Applied Microbiology, University of Tokyo. The Journal of General and Applied Microbiology, 1960. v.6, n.4, p.283292. Available from: <http://dx.doi.org/10.2323/jgam.6.283>. Accessed: Jan. 15, 2020. doi: 10.2323/jgam.6.283.

XU, Y. et al. Chitosan flocculation to aid the harvesting of the microalga Chlorella sorokiniana. Bioresource Technology, Feb. 2013. v.129, p.296-301. Available from: <http://dx.doi. org/10.1016/j.biortech.2012.11.068>. Accessed: Jan. 29, 2020. doi: 10.1016/j.biortech.2012.11.068.

ZHANG, B. et al. Effect of different organic matters on flocculation of Chlorella sorokiniana and optimization of flocculation conditions in swine manure wastewater. Bioresource Technology, Sep. 2015. v.192, p.774-780. Available from: <http://dx.doi. org/10.1016/j.biortech.2015.06.068>. Accessed: Feb. 02, 2020. doi: $10.1016 /$ j.biortech.2015.06.068

ZHU, M. Extraction of lipids from Mortierella alpina and enrichment of arachidonic acid from the fungal lipids. Bioresource Technology, Aug. 2002. v.84, n.1, p.93-95. Available from: $<$ http://dx.doi.org/10.1016/S0960-8524(02)00028-7>. Accessed: Feb. 09, 2020. doi: 10.1016/S0960-8524(02)00028-7. 